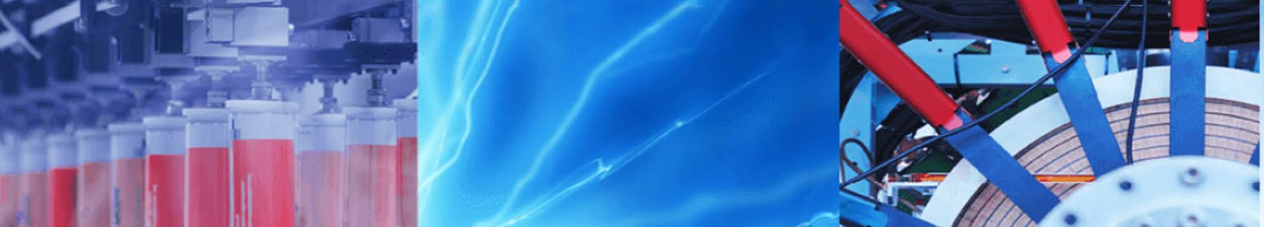

Research Article

\title{
Dynamic of channel potholes on Precambrian geological sites of Chhota Nagpur plateau, Indian peninsula: applying fluvio-hydrological and geospatial techniques
}

\author{
Biswajit Bera $^{1}$ (D) Sumana Bhattacharjee ${ }^{2} \cdot$ Arijit Ghosh $^{1,3} \cdot$ Supriya Ghosh $^{1} \cdot$ Meelan Chamling $^{1}$
}

C Springer Nature Switzerland AG 2019

\begin{abstract}
Dynamic channel bed potholes or sculpted forms (circular, elliptical, oval, elongated, etc.) on riverbeds are generally formed due to the variation of lithology with structures and dominant fluvio-hydrological processes. Most of the channel bed potholes are confined at Bhakuyadi, Guridih and Ghatsila on Precambrian Chhota Nagpur granitic gneiss and tonalite gneiss of the river Subarnarekha and its tributaries. A total of 215 channel bed potholes are studied at three sites [Site 1 Bhakuyadi $(n=115)$, Site 2 Guridih $(n=65)$ and Site 3 Ghatsila $(n=35)$ ]. The main objective is to find out the multidimensional growth on Precambrian bed rock channel and analyze the role of fluvio-hydrological factors toward their growth. Geospatial, fluvio-hydrological and statistical techniques have been applied to find out the potholes dynamic on lithological diversity of extended part of the Chhota Nagpur plateau of gneissic complex. Lineament features have been extracted using different SWIR and VNIR bands of two specific images like ETM and ASTER. Arc Hydrology tool (Hydro tool of ArcGIS) has been used to delineate stream networks and watershed of river Subarnarekha. Morphology of potholes like shape-form analysis has been done through morphometric index such as Surface Index, Bottom Index and Vertical Index. Downward and sideward potholes growth rate are calculated using mathematical indices, and depth-radius ratio has been assessed applying descriptive statistics. The results show that the multi-dimensional growth or pothole dynamics are immensely regulated by local condition such as rock types with structural imprints (fractures, joints, etc.). The absence of micro-geological structures on others lithological unit have failed to give birth to multi-dimensional growth of channel potholes along the flow path of river Subarnarekha and its tributaries within the Subarnarekha watershed. Chhota Nagpur granitic gneiss and tonalite gneiss with structural signatures help to form channel bed potholes within the flow path of river Subarnarekha and its tributaries. Statistical analysis reveals that there is a strong positive correlation between depth and radius of potholes. Subsequently, fluvio-hydrological factors (like corrasion, cavitation, hydraulic action, change of channel gradients, monsoonal bankfull discharge, etc.) clearly reflect the dynamic growth of channel bed potholes specifically during monsoonal months.
\end{abstract}

Keywords Bedform · Granitic gneiss · Indian peninsula · Lineament

\section{Introduction}

Potholes are common but significant fluvial geomorphic imprint on bed rock channel. Basically, potholes are defined as the various kinds of openings or holes in both soft and hard bed rock channels due to multi-fluvio-hydrological reasons [1]. Today, not only the stream potholes in Guangdong but also wind-eroded potholes in Hebei and glacial eroded potholes in Inner Mongolia are considered for space-specific thorough investigation

\footnotetext{
$\triangle$ Biswajit Bera, biswajitbera007@gmail.com | ${ }^{1}$ Department of Geography, Sidho-Kanho-Birsha University, Ranchi Road Purulia, Purulia, West Bengal, India. ${ }^{2}$ Department of Geography, Jogesh Chandra Chaudhuri College, Calcutta University, Kolkata, West Bengal, India. ${ }^{3}$ ICSSR Major Project, HRD Ministry, New Delhi, India.
} 
[2-4]. In recent years, process-oriented studies have been conducted on channel bed incision or bed rock potholes through multi-dimensional temporal and spatial scales [5-10] but various unanswered questions indicating discrete locational and erosional events [11, 12]. The micro-isolated or continuous circular, elliptical, triangular, oval and elongated channel bed depressions are generally exposed due to lithological, structural and dominant fluvio-hydrological attributes. The multiple sculpted forms on channel bed have already been quantified in stream hydrology $[13,14]$. In large scale, potholes are developed within the bedrock channels where mechanically weak zones such as intersection between vertical and horizontal joints, multiple joints and finally fluvio-hydrological processes like abrasion, corrosion and cavitation are much more active [15]. Local channel bed weathering processes enhance the development of potholes [16]. Goode and Wohl [17] also considered erosional bed forms such as grooves, immobile rocks and boulder obstructions that are partial reasons behind the development of small channel potholes. Based on empirical data, a mathematical model has been designed to grow potholes considering the radius and depth $[12,18]$.

Alexander [19] classified potholes into three types on the basis of their origin: (1) eddy holes; (2) gouge holes; and (3) plunge pool holes. Based on morphology, potholes are also classified into vertical and lateral types. Cylinder or circular-shaped vertical potholes exposed on the channel floors that have depth comparable to their width and complete circumferences but where subsequent breaching occurs such shape gets distorted [20] in case of lateral potholes that are located on the sides of the channel embankment which have incomplete circumferences and are generally found in groups on the channel bed outcrop in the downstream direction. Such potholes are not circular in view with over hanging roofs with superficially tafoni alike [21]. Generally, the lateral potholes are found in conical basins and these are usually submerged during bankfull discharge [22]. Thompson [23] clearly highlighted that lateral potholes are not completely breached with respect to vertical potholes due to the location on the flank of the channel. Vertical potholes shape develop where the mixing length of the vortex with respect to water depth is higher [24].

A scientific study conducted in upper Dingjiang River (China) on multiple channel potholes development reveals that there was no as such relationship between joints and granite bedrocks [25], whereas another study on Shiduxi River also shows that granite bedrock channel and joints are influencing the development of potholes [26]. Similarly in the inland of northern China, the long axes of wind formed potholes are largely controlled by climatic factors and these are exposed on granitic rock [27]. The fundamental relationship between mean radius or diameter and depth of stream potholes is log linearity trend $[12,18]$.

Micro-channel bed feature or pothole is exposed in different locations on the channel bed of Subarnarekha and its tributaries. It is assumed that this spectacular channel bedrock feature is well developed by active fluvio-hydrological processes and geological factors through hundreds to thousands of years. The main objective of the scientific study is (1) to ascertain the reasons behind uneven and multi-dimensional growth of potholes along the bedrock channel path and (2) to find out fluvio-hydrological response to pothole growth.

\section{Materials and methods}

\subsection{Area of the study}

The rain-fed river Subarnarekha originates near Nagri village $\left(23^{\circ} 18^{\prime} 02^{\prime \prime} \mathrm{N}\right.$ and $\left.85^{\circ} 11^{\prime} 04^{\prime \prime} \mathrm{E}\right)$ in the Ranchi district of Jharkhand. Out of the total travel distance of $395 \mathrm{~km}$, $269 \mathrm{~km}$ flows in Jharkhand, $64 \mathrm{~km}$ in West Bengal and $62 \mathrm{~km}$ in Odisha. The catchment area of Subarnarekha River is about $19,296 \mathrm{sq} . \mathrm{km}$ and lies between $21^{\circ} 29^{\prime} \mathrm{N}$ to $23^{\circ} 33^{\prime} \mathrm{N}$ and $85^{\circ} 9^{\prime} \mathrm{E}$ to $87^{\circ} 27^{\prime} \mathrm{E}$. It flows in the northeast corner of the Chhota Nagpur plateau of the Indian peninsula. Literally, the word Subarnarekha means 'Streak of Gold' [28, 29]. The main right bank tributaries of Subarnarekha River are Rarhu (50 km), Kanchi (80 km), Karkari (120 km), Kharkai $(145 \mathrm{~km})$, Garra $(55 \mathrm{~km})$ and Sankh $(30 \mathrm{~km})$, and the left hand tributaries are Jhumar (35 km) and Dulung $(75 \mathrm{~km})$ (Table 1). In ancient time, gold was mined at a village Piska near the source of the river. Kharkai is the largest tributary of the Subarnarekha which originates from the Simlipal massif in Mayurbhanj district (Odisha) and it is also called as gold-bearing river. The placer gold deposit is also found in the bed of some tributaries of Kharkai River like Sanjai, Sanhua and Bonai [30]. Numerous channel bed potholes are immensely confined in different stretches of Subarnarekha and its tributaries, but three dominant sample sites [Site 1 Bhakuyadi $(n=115)$, Site 2 Guridih $(n=65)$ and Site 3 Ghatsila $(n=35)]$ have considered for detailed study. The geographic coordinates of the above-mentioned sites are-(i) Site 1 Bhakuyadi $\left(23^{\circ} 13^{\prime} 13.8504^{\prime \prime} \mathrm{N} ; 85^{\circ} 51^{\prime} 30.2688^{\prime \prime} \mathrm{E}\right)$, Site 2 Guridih $\left(23^{\circ} 20^{\prime} 26.1888^{\prime \prime} \mathrm{N} ; 85^{\circ} 36^{\prime} 31.68^{\prime \prime} \mathrm{E}\right)$ and Site 3 Ghatsila

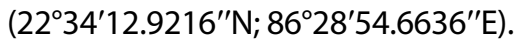

\subsection{Output of different thematic maps applying geospatial methods}

\subsubsection{Lithological map}

For the comprehensive study on irregular distribution of channel bedrock potholes, lithological map (Fig. 1) of 
Table 1 Important right and left bank tributaries with their catchment area (in sq.km) of Subarnarekha River. Source: Survey of India (19231979)

\begin{tabular}{|c|c|c|c|c|c|c|}
\hline Sl. no. & Name of the important tributary & Left/right bank & Total length in km & $\begin{array}{l}\text { Catchment } \\
\text { area in sq.km }\end{array}$ & $\begin{array}{l}\text { Total basin } \\
\text { area in } \%\end{array}$ & $\begin{array}{l}\text { Annual yield in } \\
\text { million cubic } m\end{array}$ \\
\hline 1. & Rarhu & Right & 50.00 & 622.00 & 3.22 & 250.00 \\
\hline 2. & Kanchi & Right & 80.00 & 103.60 & 5.37 & 750.00 \\
\hline 3. & Karkari & Right & 120.00 & 1575.00 & 8.17 & 950.00 \\
\hline 4. & Kharkai & Right & 145.00 & 5825.00 & 30.19 & 3300.00 \\
\hline 5. & Garra & Right & 55.00 & 483.00 & 2.50 & 200.00 \\
\hline 6. & Sankh & Right & 30.00 & 196.00 & 1.02 & 80.00 \\
\hline 7. & Jumar & Left & 35.00 & 182.00 & 0.94 & 70.00 \\
\hline 8. & Dulung & Left & 75.00 & 1173.00 & 6.08 & 500.00 \\
\hline 9. & Remaining streams of right bank & Right & & 4812.00 & 24.94 & 970.00 \\
\hline \multirow[t]{2}{*}{10.} & Remaining streams of left bank & Left & & 4760.00 & 17.64 & 870.00 \\
\hline & Total & & & $19,296.00$ & 100.00 & 7940.00 \\
\hline
\end{tabular}

Geological Survey of India has been used and digitized by ArcGIS 10.5 software following the geographic coordinate systems (WGS: 1984, WKID: 4326, Authority: EPSG). Both Precambrian bedrock type and alluvial/gravel terraces are formed within the tributaries of Subarnarekha river. These are draining from the western margin of the Ranchi plateau such as Raru, Kanchi, Garra, Kharkai and Jamir [30]. Various Precambrian high-grade metamorphic and igneous rocks as well as alluvium deposits have also been thoroughly identified in different pockets of Subarnarekha River and its tributaries. Moreover, first- and second-generation structural imprints have been detected through handheld Garmin GPS Etrex $30 \times$ receiver during field visit at different sample sites. Gecoding method has been applied to know the actual location of the sites of potholes. After extraction of lineaments from the satellite image on remote sensing platforms, few cross-verification study has also been conducted.

\subsubsection{Elevation, slope, slope aspects and drainage network}

Shuttle Radar Topography Mission (SRTM) digital elevation model (DEM) data of study area have been download from https://earthexplorer.usgs.gov/. DEM of the Subarnarekha
Fig. 1 Geological map with stream network of Subarnarekha watershed

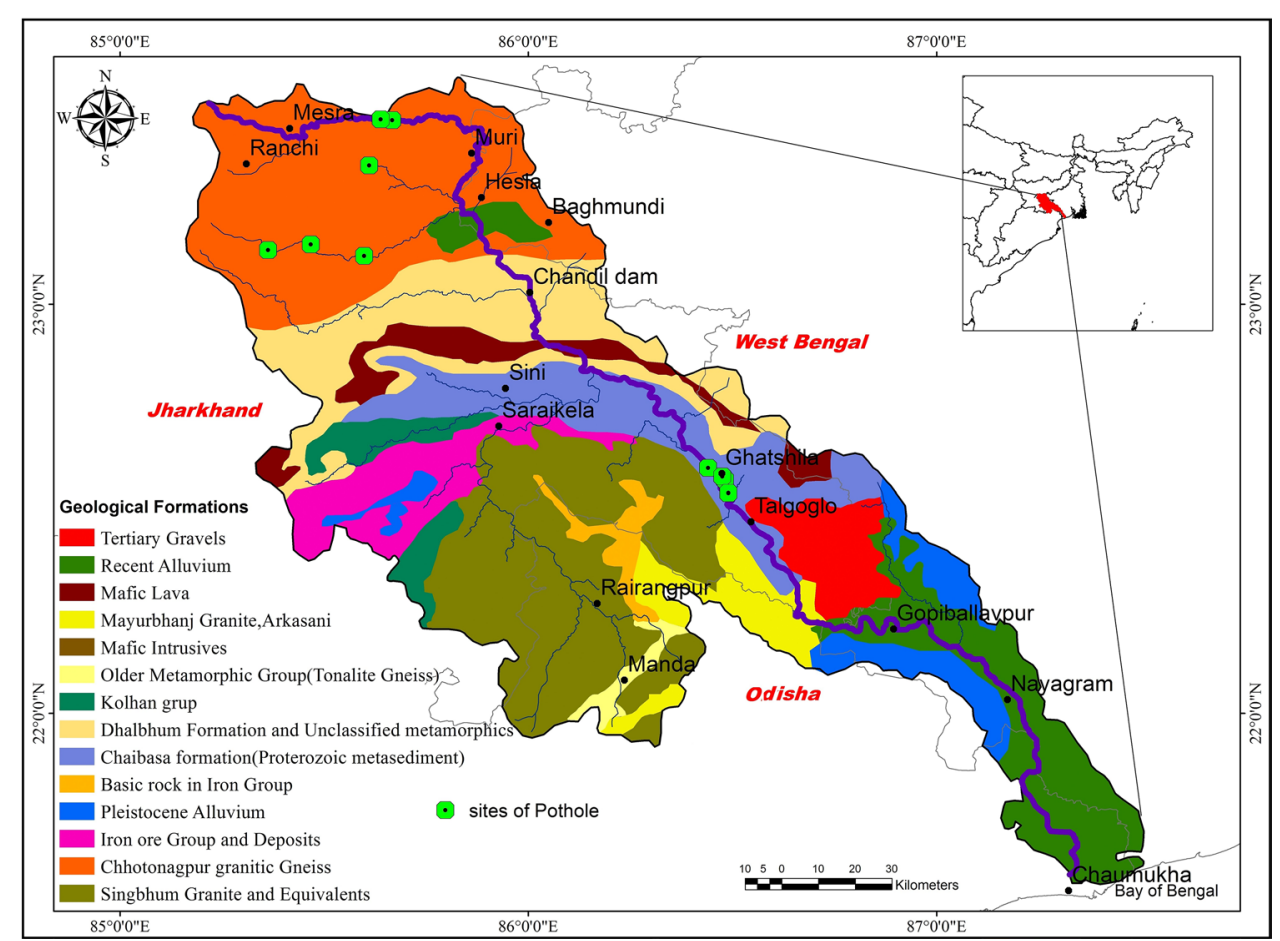

SN Applied Sciences A SPRINGER NATURE journal 
watershed has been reprojected in Universal Transverse Mercator (UTM), Zone 45N from geographic coordinate systems (WGS 1984) to get the actual ground elevation ( $Z$ value). This watershed DEM consists of $2,483,095$ pixels having $90 \mathrm{~m}$ spatial resolution. Using spatial analysis surface tool, automatically slope (value) and slope aspect (direction) have been extracted and reclassified into nine zones (Fig. 2) (Table 2). Applying ArcHydro tool on ArcGIS 10.5 software platform, original DEM has been transferred to filled DEM. Flow accumulation is calculated from the flow direction grid. Each pixel was given a value equal to the number of pixels which is drained through a given pixel for the flow accumulation. The stream network (Fig. 2) is extracted by assigning the pixels higher than the threshold of 250 using the raster calculator. Trial and error method has been used for minimum accumulation threshold value in bedrock channel [31, 32].

\subsubsection{Delineation of watershed}

Watershed of the Subarnarekha is delineated using SRTM DEM and topographical map. SRTM DEM and topographical map are maneuvered in ArcGIS 10.5 software using the ArcHydro tools following projected coordinate systems (WGS 1984, UTM Zone $45 \mathrm{~N}$ ). The projected coordinate system is applied for the calculation of watershed area, drainage basin area, length of the river and other geomorphic features of the study area. The principal water divide of Subarnarekha River is delineated from topographical maps using manual digitizing of the black line in ArcGIS. Survey of India topographical maps scaled at 1:50,000 are georeferenced using UTM projection (Zone $45 \mathrm{~N}$ ) which is the national coordinate system. Secondly, drainage network is extracted from DEM having 20-m contour interval applying the hydrology tool set in ArcGIS. Various methods
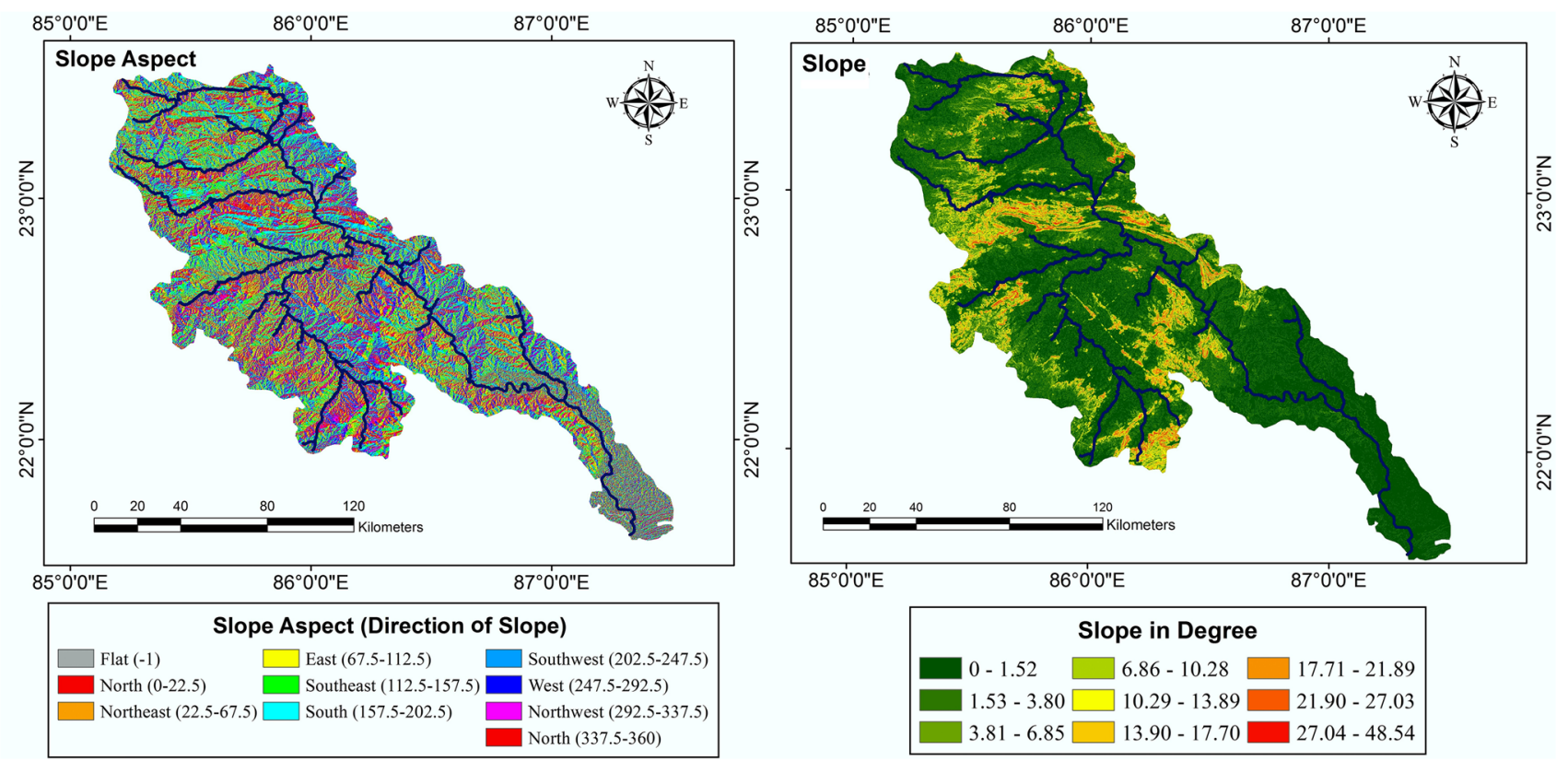

Fig. 2 Slope and slope aspect map of Subarnarekha watershed prepared by using SRTM DEM

Table 2 Slope and slope aspects extracted from SRTM DEM using ArCGIS 10.5

\begin{tabular}{lcl}
\hline Class & Slope value in degree & Slope aspects \\
\hline Class I & $0-1.52$ & Southeast, east, north, flat \\
Class II & $1.53-3.80$ & South, southwest, north, southwest \\
Class III & $3.81-6.85$ & South, southeast, southeast, north, flat \\
Class IV & $6.86-10.28$ & Southwest, southeast, north, northwest, south \\
Class V & $10.29-13.89$ & West, south, southwest, flat \\
Class VI & $13.90-17.70$ & Southwest, north, east \\
Class VII & $17.71-21.89$ & East, southwest, southeast, flat \\
Class VIII & $21.90-27.03$ & West, southeast, north, flat \\
Class IX & $27.04-48.54$ & North, east, southwest, flat \\
\hline
\end{tabular}


and techniques have been applied for extracting the drainage networks from DEM which is documented in different literatures [33-37].

\subsubsection{Extraction of lineament}

Lineaments are basically linear or curvilinear features of structural weakness of the earth surface that is detected from the imageries applying geospatial techniques. Lineament features have been extracted using different bands of two specific images, namely ETM and ASTER. ETM image is composed of 6 VNIR and SWIR bands with a spatial resolution of $30 \mathrm{~m}$ along with the panchromatic band 8 of $15 \mathrm{~m}$ spatial resolution. On the other hand, ASTER image consists of 3 VNIR bands having a spatial resolution of

Table 3 Parameters used for the $\mathrm{PCl}$-line module of each data kind, FTHR-specific threshold for error fitting, LTHR-specific threshold for curve length, RADI-specific radius of filter (pixels), ATHR—specific threshold for angular differences, DTHR—specific threshold for distance link (pixel), GTHR-specific threshold for gradient (in edge pixel) (PC Geomatica V 9.1.0 Guide, 2003)

\begin{tabular}{llc}
\hline SI no. & Parameters & $\begin{array}{c}\text { ETM and ASTER } \\
\text { image values }\end{array}$ \\
\hline 1. & FTHR & 3 \\
2. & LTHR & 30 \\
3. & RADI & 10 \\
4. & ATHR & 30 \\
5. & DTHR & 20 \\
6. & GTHR & 100 \\
\hline
\end{tabular}

$15 \mathrm{~m}$ and SWIR bands of $30 \mathrm{~m}$ spatial resolution. These images are fused, and the lineaments are extracted from the bands following LINE module based on edge filtering techniques using PCl Geomatica V 9.1.0 software (Table 3).

\subsubsection{Lineament density}

Using frequency or length against azimuth histograms [38, $39]$, and lineament density maps $[39,40]$, subsequently lineaments are analyzed. A lineament density index of study area is calculated considering the total length of lineaments per unit area $\left(\mathrm{km} / \mathrm{km}^{2}\right)$ as follows: $L=\sum_{i=1}^{N} x i$ $\mathrm{km} / \mathrm{km}^{2}$ where $L$ stands for total length of lineament, $N$ for number of lineament and $x_{i}$ for length of lineament number $i$. The watershed is categorized into five lineament density zone (Fig. 3). There is a close relationship between lineament density and multi-directional growth of potholes on bedrock channel of Subarnarekha and its tributaries in the extended part of the Chhota Nagpur plateau of Indian peninsula. Micro-lineament length and density have calculated from three sample sites [Site 1 Bhakuyadi $(n=115)$, Site 2 Guridih $(n=65)$ and Site 3 Ghatsila $(n=35)]$ on remote sensing platform.

\subsection{Fluvio-hydrological techniques}

\subsubsection{Erosional matrix of potholes growth}

Fluvio-hydrological phenomenon accelerates the dynamics of bedrock channel potholes and specifically downward $(z)$ and outward $(y)$ growth that depends on
Fig. 3 Lineament density map using ETM and ASTER image consisting of three VNIR bands having a spatial resolution of $15 \mathrm{~m}$ and SWIR bands of $30 \mathrm{~m}$ spatial resolution

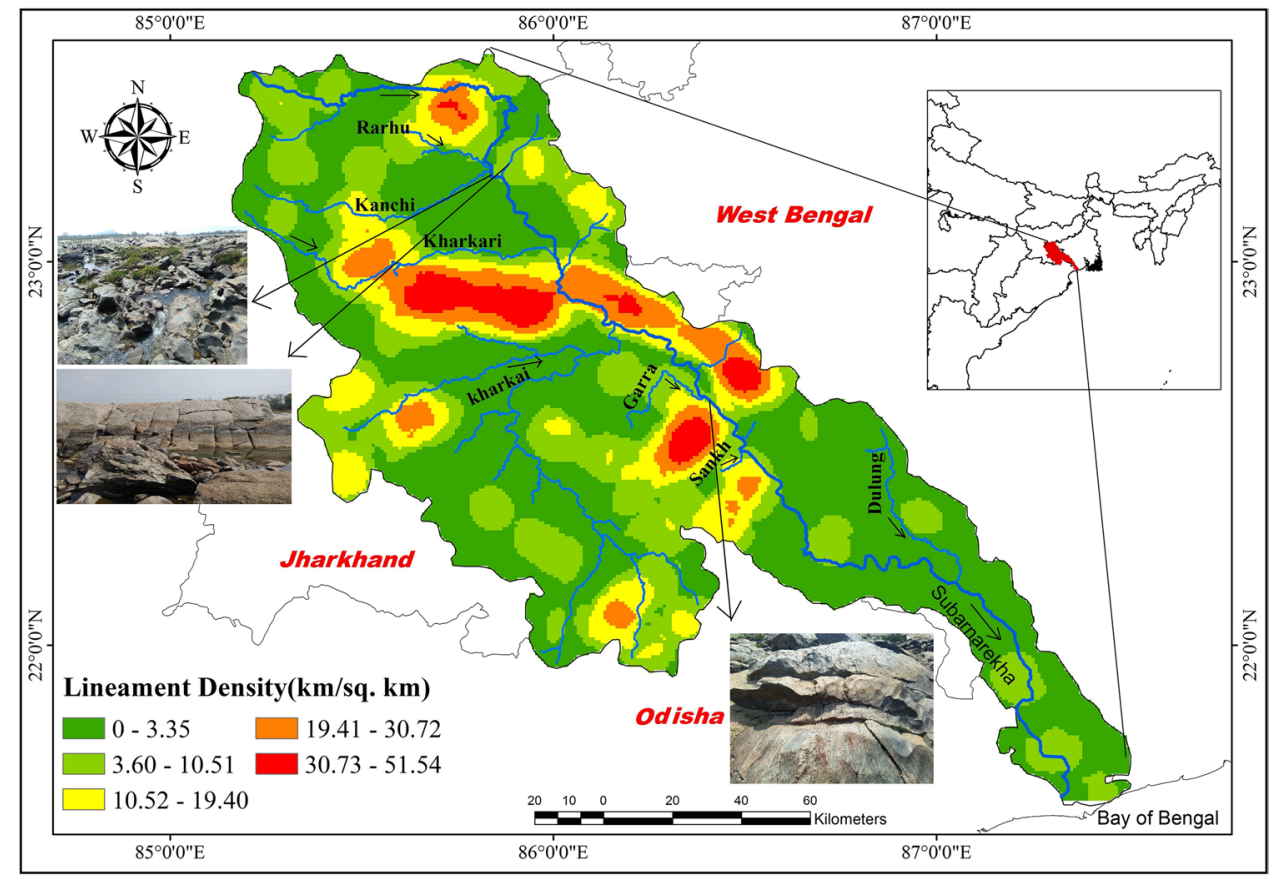

SN Applied Sciences A SPRINGer NATURE journal 
spatial distribution of surface erosion rate. Depth and radius ratio often simulates architectural growth of potholes. Generally, space-time-specific downward growth may be decreased or increased but outward or wall side growth is not restricted in case of exposed lineaments on bedrock channel. Volume of erosion of floor and wall is quantified by the general equations $\left(V_{w} / S_{w}\right.$ where $V_{w}$ is the volume eroded from the wall and $S_{w}$ is the wall surface area) and regulated by the spatial variation of surface erosion rates.

Pothole dimensions or dynamics largely depend on ratio between depth and radius applying the equation

$\bar{r}=k d^{\varepsilon}$

where $r$ is radius, $d$ stands for depth, $k=2.3$ (constant value) and $\varepsilon=0.57$ (constant value). The relationship between $d$ and $r$ is calculated from different stretches of the channel and plotted on the graph.

Pothole dynamics or the enlargement of the depth and radius along the $z-y$ plane requires energy or current of the water along with accompanying sediments and it is expressed by $y=k z^{\varepsilon}$ and the volumetric change of pothole floor and side walls can be expressed by integrating Eq. (1) along with the $z$ axis,

$V_{f}=\pi k^{2} \int_{Z n}^{Z n+1} Z^{2} \mathrm{~d} z$

where $V_{f}$ stands for total volume eroded from a pothole floor between two space-time intervals $(n, n+1), Z$ is the primary location of the pothole and $k$ is the regression coefficient.

The quantification of the volume of eroded materials from the above site can be obtained by applying the equation

$2 Z_{n} \int_{Y_{n}}^{Y_{n+1}} y d y$

where $y$ stands for radius of the potholes, $\mathrm{Zn}$ is the erosional depth, $Y n$ is primary radius and $Y n+1$ is the secondary radius of the potholes. The enlargement of the size of the pothole from the initial to secondary step can be derived by applying the equation

$\pi(\mathrm{Zn}+1-\mathrm{Zn}) \mathrm{y}_{n+1}^{2}-\pi k^{2} \int_{\mathrm{Zn}}^{\mathrm{Zn}+1} z^{2 \varepsilon} \mathrm{d} z$.

where $\mathrm{Zn}$ is the initial floor of pothole, $\mathrm{Zn}+1$ stands for erosional pothole floor at secondary stage and $k$ means regression coefficient.

\subsubsection{Morphometric parameters of potholes}

Around 215 samples of potholes have been collected from the three sites [Site 1 Bhakuyadi $(n=115)$, Site 2 Guridih $(n=65)$ and Site 3 Ghatsila $(n=35)]$ of Subarnarekha River in the year 2017-2018 and important morphometric parameters like (1) maximum vertical depth (D), (2) largest diameter of the surface $\left(S_{\max }\right)$, (3) smallest diameter of the surface $\left(S_{\min }\right)$, (4) largest diameter at the bottom $\left(B_{\max }\right)$, (5) smallest diameter at the bottom $\left(B_{\min }\right),(6)$ external shape, etc., are used to analyze the relationship between them. Similarly to understand the site specific relationship between the above-mentioned variables for the growth of potholes, three important morphometric indexes are also applied like (1) surface Index $\left(S I=S_{\max } / S_{\min }\right)$, (2) Bottom Index $\left(\mathrm{BI}=B_{\max } / B_{\text {min }}\right)$ and $(3)$ Vertical Index $\left(\mathrm{VI}=\mathrm{D} / \mathrm{rs}_{\max }\right)$.

\subsection{Statistical techniques}

An exploratory analysis is done to find out the dimensional relation among the parameters, and suitable statistical techniques have also been applied to know the consistency and actual relationship between the variables. Correlation $\left(r=\frac{n\left(\sum x y\right)-\left(\sum x\right)\left(\sum y\right)}{\sqrt{\left[n \sum x^{2-\left(\sum x\right) 2}\right]\left[n \sum y^{2-\left(\sum y\right) 2}\right]}}\right)$, standard deviation $\left(\mathrm{SD}=\sqrt{\frac{\sum(x-\bar{x}) 2}{n}}\right)$ and coefficient of variation $\left(C V=\frac{S D}{M e a n} \times 100 \%\right)$ are applied to reveal multi-dimensional growth rate of the potholes on the bedrock channel of Subarnarekha and its tributaries.

\section{Results}

\subsection{Pothole dynamics at different Precambrian geological sites}

\subsubsection{Relationship between lithology and lineament}

According to Geological Survey of India (GSI), Indian Shield is occupied in most of the part of Subarnarekha river basin and Precambrian igneous and metamorphic rocks are also exposed in different parts of the basin. Similarly, Younger geological formation such as Tertiary gravels/sediments, Pleistocene alluvium and Holocene alluvium is also occupied in the lower part of the Subarnarekha river basin mainly in the south and southeastern part of Ghatsila. The principal lithological associations are Chhota Nagpur granitic gneiss, Proterozoic metasediment (Chaibasa formation), iron ore group with iron ore deposits, Tertiary gravels, Singhbhum granite, recent alluvium, Pleistocene 
alluvium, older metamorphic group, basic rock in iron ore group, Mayurbhanj granite, Mafic lava, Mafic intrusive, Kolhan group and Dhalbhum formation with metamorphic. The various age rock formations are found throughout the basin of the Subarnarekha. The older metamorphic group of rocks ( 3.8 billion years old) with tonalite gneiss is confined in the Mayurbhanj district of Odisha, and recent alluvium which is deposited on the lower part of the basin is basically toward the Bay of Bengal at the mouth of the river. These principal litho-units consist of iron, copper, gold, limestone, dolomite, chinaclay, uranium, chromium, vanadium, kyanite, asbestos, apatite, talc, etc.

Dominant sites of channel bed potholes have been identified on the channel bed of Subarnarekha and its tributaries (Table 4).

Except Garanala confluence point (metasediment), all the sites are situated on Chhota Nagpur granitic gneiss and tonalite gneissic belt. Prominent large-sized and multi-dimensional growth of potholes is confined mostly on the upstretch of Subarnarekha and its tributaries like Rarhu and Kanchi due to its moderate to high lineament density (10.5-19.40 km/sq.km) although high to very high (19.41-30.72 and 30.73-51.54 km/sq.km) lineament density (Fig. 3) has been confined in the elevation zones of 321-500 m and 201-960 m within the Subarnarekha watershed. There are no surface or subsurface streams which are flowing on the high/very high elevation zones (Fig. 2), but all channel bed pothole sites are located between $0^{\circ}-2.60^{\circ}$ and $2.61^{\circ}-7.40^{\circ}$ slope zones. High lineament density and very high lineament density (19.41-30.72 and 30.73-51.54 km/sq.km) are found on Dhalbhum formation and unclassified metamorphic, metasediment, tonalite gneiss, Singhbhum granite, etc.

\subsubsection{Fluvio-hydrological response to potholes growth}

As Subarnarekha watershed is situated in the moderate to high rainfall zone of Indian Peninsula, it receives significant volume (about 28,609 million cubic meters) of precipitated water (June-September) every year [28], while in the non-monsoonal months, Subarnarekha and its tributaries run almost dry path. If the whole year is taken into consideration (Table 5 ), the annual mean river discharge stands $392 \mathrm{~m}^{3} / \mathrm{s}$ (13,843 cubicft/s). Around 20 different sized multipurpose dams/reservoirs have been constructed across the Subarnarekha River and its tributaries (Source: Water Resources Information System of India, 2014). As a result, its upper and middle reaches become sluggish and behave like a stagnant water pool during dry seasons. Fluvio-hydrological processes play a significant role for spatiotemporal growth of channel bed potholes [41]. Monsoonal rainfall and subsequently fluvio-hydrological parameters help to enlarge channel bed potholes as well as give birth to new potholes on rejuvenated channel beds of Chhota Nagpur plateau of Indian Peninsula [42]. Landscape morphology and fluvial hydrodynamics also directly influence to grow new potholes on highly jointed and fractured channel bed of Precambrian rocks (Chhota Nagpur plateau) (Fig. 4). Monsoonal flood with bankfull discharge eventually affects the growth of potholes and occasionally creates its new form [43]. On the upstretch of Subarnarekha River, knickpoints accelerate stream energy and simultaneously channel planform has been subsequently modified due to the variation of river hydrodynamic processes.

Table 4 Dominant pothole sites on different surface litho-units within the Subarnarekha watershed

\begin{tabular}{|c|c|c|c|c|c|}
\hline \multirow{2}{*}{$\begin{array}{l}\text { Sl. no. of the } \\
\text { sample sites }\end{array}$} & \multirow[t]{2}{*}{ River } & \multirow[t]{2}{*}{ Landmarks/places } & \multicolumn{2}{|l|}{ Coordinates } & \multirow[t]{2}{*}{ Dominant surface lithology } \\
\hline & & & Latitude (N) & Longitude (E) & \\
\hline 1. & Subarnarekha & Near Bhakuyadi & 23.220525 & 85.857749 & Chhota Nagpur granitic gneiss \\
\hline 2. & Rarhu & Guridih (near Jonha Falls) & 23.340143 & 85.610417 & Chhota Nagpur granitic gneiss \\
\hline 3. i. & $\begin{array}{l}\text { Subarnarekha-Lokjhoria con- } \\
\text { fluence }\end{array}$ & Near Haridungri (Ghatsila) & 22.570309 & 86.482017 & Tonalite Gneiss \\
\hline 3.ii. & $\begin{array}{l}\text { Subarnarekha-Kharsoti conflu- } \\
\text { ence }\end{array}$ & Bagula (Ghatsila) & 22.538456 & 86.490046 & Tonalite Gneiss \\
\hline 3.iii. & Subarnarekha & Moubhandar (near Ghatsila) & 22.599789 & 86.440165 & Tonalite Gneiss \\
\hline 3.iv. & Subarnarekha & Near Nuagoan (near Ghatsila) & 22.578835 & 86.475202 & Tonalite Gneiss \\
\hline 4. & Subarnarekha & Malghonghsa & 23.452903 & 85.638523 & Chhota Nagpur granitic gneiss \\
\hline 5. & Kanchi & Tarub (near Dassam Falls) & 23.146592 & 85.467152 & Chhota Nagpur granitic gneiss \\
\hline 6. & Kanchi & Taro & 23.133134 & 85.362399 & Chhota Nagpur granitic gneiss \\
\hline 7. & Kanchi & Near Pangura & 23.118612 & 85.598102 & Chhota Nagpur granitic gneiss \\
\hline 8. & Subarnarekha & Saram (near Hundru Falls) & 23.45086 & 85.666802 & Chhota Nagpur granitic gneiss \\
\hline 9. & Subarnarekha & Near Garanala & 22.644231 & 86.390832 & Proterozoic metasediment \\
\hline
\end{tabular}


Table 5 Hydro-geomorphological detail of Subarnarekha River

\begin{tabular}{|c|c|c|c|c|c|c|c|c|}
\hline \multicolumn{6}{|c|}{ Catchment area in different states } & \multirow{3}{*}{$\begin{array}{l}\text { Total } \\
\text { length } \\
(\mathrm{km})\end{array}$} & \multirow{3}{*}{$\begin{array}{l}\text { Mean width } \\
\text { (m) }\end{array}$} & \multirow{3}{*}{$\begin{array}{l}\text { Mean } \\
\text { discharge } \\
\text { (cubic m/ } \\
\text { sec) }\end{array}$} \\
\hline \multicolumn{2}{|l|}{ Jharkhand } & \multicolumn{2}{|l|}{ Odisha } & \multicolumn{2}{|l|}{ West Bengal } & & & \\
\hline $\begin{array}{l}\text { Catchment } \\
\text { area (sq.km) }\end{array}$ & $\begin{array}{l}\text { Percentage } \\
\text { (\%) }\end{array}$ & $\begin{array}{l}\text { Catchment } \\
\text { area (sq.km) }\end{array}$ & $\begin{array}{l}\text { Percentage } \\
\text { (\%) }\end{array}$ & $\begin{array}{l}\text { Catchment } \\
\text { area (sq.km) }\end{array}$ & $\begin{array}{l}\text { Percentage } \\
\text { (\%) }\end{array}$ & & & \\
\hline $13,193.00$ & 98.40 & 3114.00 & 16.10 & 2989.00 & 15.50 & 395 & 1123.85 & 392 \\
\hline \multicolumn{9}{|c|}{ Total catchment area-19,296.00 sq.km } \\
\hline \multicolumn{9}{|c|}{ Total catchment area-100.00\% } \\
\hline
\end{tabular}

(i) Out of nine sites, three sample sites (where sculpted potholes Site $1 n=115$, Site $2 n=65$ and Site 3 $n=35$ ) have been selected and various field data were collected for detailed study. Applying Eq. (1), the dynamic growth of potholes shows positive relationship between depth and radius among these above-mentioned three sites [Bhakuyadi
( $n=115)$, Guridih ( $n=65)$ and near Ghatsila $(n=35)]$. As the Subarnarekha and its tributaries (in case of upstretch) are flowing on rejuvenated landform, channel flow paths are restricted within the narrow passage (in case of Chhota Nagpur granitic gneiss and tonalite gneiss). Sudden monsoon river flow velocity and fluvial erosional processes tend

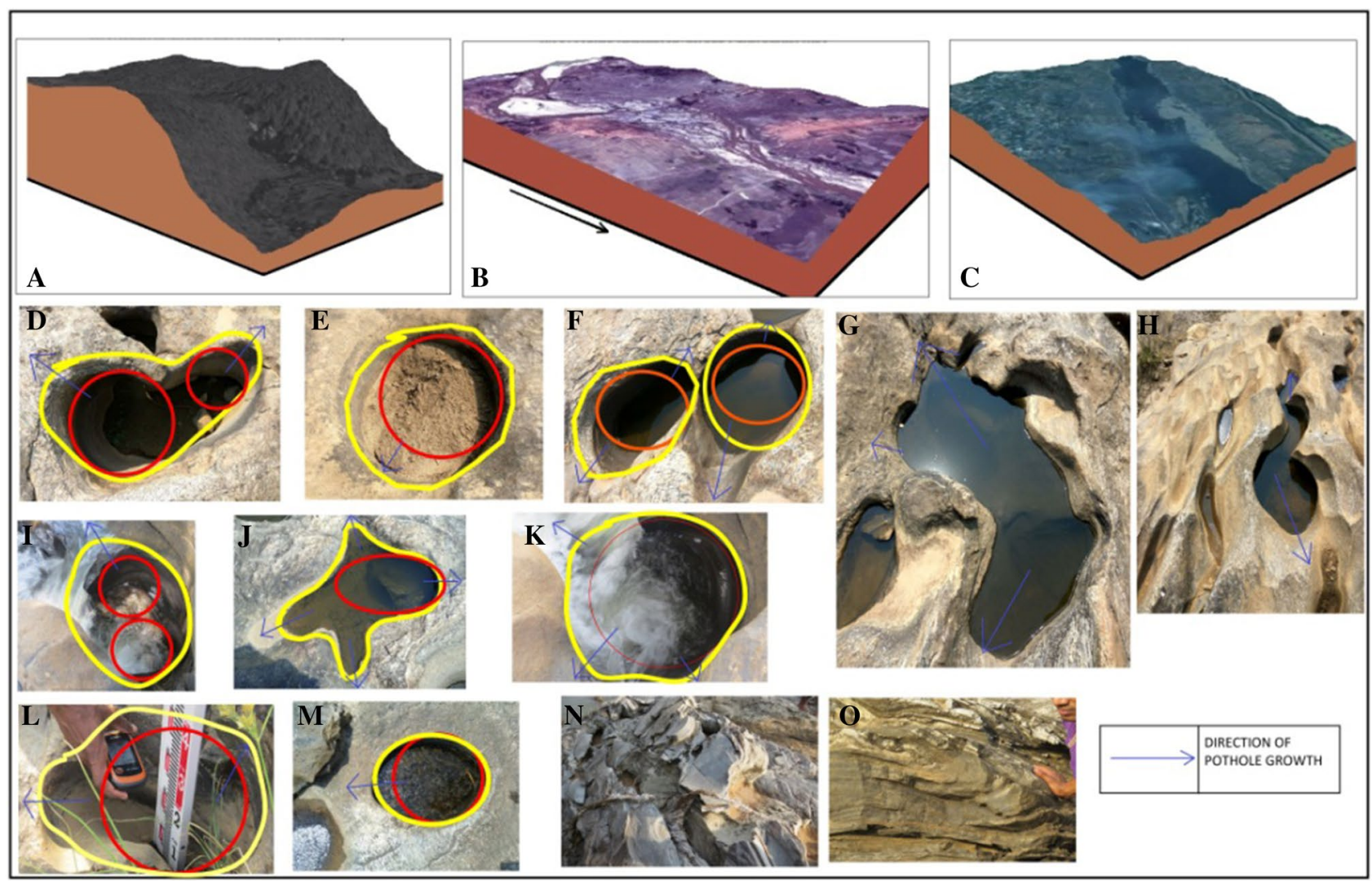

Fig. 4 3D model of stream up-stretch of Subarnarekha river generated by using Google Earth and ArcGIS 10.5 software. (A) Upper stretch (B) Middle stretch (C) Lower stretch of Subarnarekha river (D) lateral potholes growth into elliptical shape (E) round shape pothole with infilled sediments $(F)$ amalgamation of two potholes $(\mathrm{G})$ elongated shape pothole $(\mathrm{H})$ new micro sculpted potholes on structural weakness (I) side all growth of potholes (J) multi-directional growth of potholes along the existing structural weakness (K) plunge pool hole (L) volumetric change of potholes from initial area to secondary area $(\mathrm{M})$ pothole with micro habitat $(\mathrm{N})$ new birth of potholes along the joints and fractures $(\mathrm{O})$ prominent horizontal joints on granitic gneiss at Bhakuyadi site

\section{SN Applied Sciences}


to enlarge multi-directional growth of potholes along the existing structural weakness (Fig. 4). The relationship between $d$ and $r$ is calculated from three sites of the channel and plotted on the graph (Fig. 5).

(ii) Applying Eqs. (2) and (3), the study brings the enlargement of the depth and radius along the $z-y$ plane ( $z$-downward and $y$-outward) and the volumetric change of potholes floor and side wall. Applying Eq. (2) Zn $\int_{Y n}^{Y n+1} y d y$ in site 1 Bhakayudi $(n=115)$, two samples have been measured. From sample 1, we got $y=110 \mathrm{~cm}$ (radius of the pothole), $\mathrm{Zn}=190 \mathrm{~cm}$ (erosional depth), $\mathrm{Yn}=110 \mathrm{~cm}$ (primary radius), $Y \mathrm{n}+1=120 \mathrm{~cm}$ (secondary radius). The initial area of the pothole was $144,508.56$ cubic $\mathrm{m}$, whereas the secondary area was found to be $171,977.13$ cubic $m$. Thus, the pothole area has been enlarged by $27,468.57$ cubic $m$ ( 1.19 times). Similarly, in case of sample $2, y=85$ (radius of the pothole), $\mathrm{Zn}=120 \mathrm{~cm}$ (erosional depth), $\mathrm{Yn}=85 \mathrm{~cm}$ (primary radius), $\mathrm{Yn}+1=97 \mathrm{~cm}$ (secondary radius). The data recorded show that the pothole has grown from $54,497.14$ cubic $m$ (from initial area) to nearly $70,970.74$ cubic $m$ area in the secondary areas, resulting in the growth of $16,473.60$ cubic $m$ area with 1.30 times.

(iii) Applying Eq. (4), it is clearly stated that the enlargement of the size of the potholes from the initial stage to secondary stage is due to shifting of vortex of turbulent flow along the flow direction and simultaneously circular- or round-shaped potholes are converted to elliptical, oval and sometime elongated shaped depression. At sample Site 1 Bhakuyadi $(n=115)$, it has been noticed that large-sized elongated or elliptical potholes engulfed many small sculpted channel bed potholes due to multidirectional growth along the joints and fractures on the granitic gneiss channel bed of Subarnarekha
(Fig. 4). Applying Eq. (4), total area of the individual of the pothole is calculated (depth and diameter), and further considering the length of the joints/ fractures and expected circumference, the displace material will be calculated.

\subsection{Morphology of potholes}

\subsubsection{Shape-form analysis applying morphometric and statistical parameters (Site 1 Bhakuyadi $n=115$ )}

Various statistical and morphometric parameters have been applied to analyze the spatial relationship between and among the variables. In case of sample Site 1 Bhakuyadi $n=115$ (Table 6), the largest surface and bottom diameters $\left(S_{\max }\right.$ and $\left.B_{\text {max }}\right)$ are $220.00 \mathrm{~cm}$ and $170.00 \mathrm{~cm}$, respectively, whereas the smallest diameters at the surface and bottom $\left(S_{\min }\right.$ and $\left.B_{\min }\right)$ are $42.00 \mathrm{~cm}$ and $37.00 \mathrm{~cm}$. On the other hand, the maximum vertical depth (D) is $190.00 \mathrm{~cm}$, while mean depth is $60.96 \mathrm{~cm}$. Statistical parameter like coefficient of variation in $\%(\mathrm{cv})$ shows that $S_{\max }$ and $B_{\max }$ are more consistent with respect to $S_{\min }$ and $B_{\min }$. From the sculpted forms $(n=115)$ applying the parameters $S_{\text {max }}$ $S_{\min }, B_{\max }, B_{\min }$ and $\mathrm{D}$ and their interrelationship, it is found that 76 potholes are in cylindrical, 14 in elliptical and 25 in elongated forms.

\subsubsection{Shape-form analysis applying morphometric and statistical parameters (Site 2 Guridih $n=65$ )}

With respect to sample Site 2 Guridih $n=65$ (Table 7), the largest surface and bottom diameters $\left(S_{\max }\right.$ and $\left.B_{\max }\right)$ are $190.00 \mathrm{~cm}$ and $126.00 \mathrm{~cm}$, respectively, whereas the smallest diameters at the surface and bottom $\left(S_{\min }\right.$ and $\left.B_{\min }\right)$ are $17.00 \mathrm{~cm}$ and $15.60 \mathrm{~cm}$. On the other hand, the maximum vertical depth (D) is $165.00 \mathrm{~cm}$, while mean depth is $38.20 \mathrm{~cm}$. Coefficient of variation (in \%) shows that $S_{\max }$ and $B_{\max }$ are more consistent with respect to
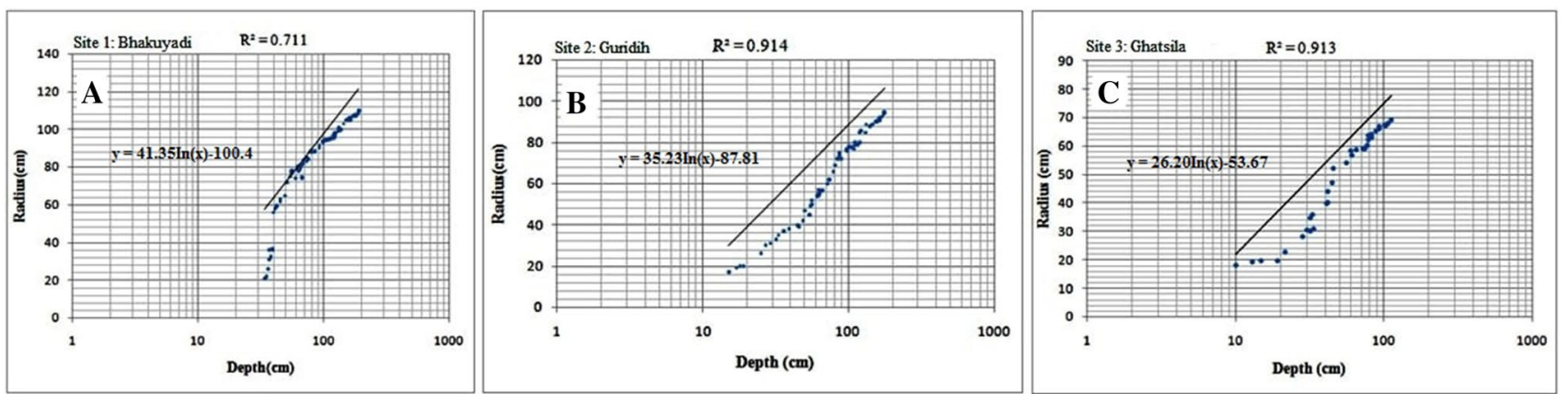

Fig. 5 Plot of pothole radius $(r)$ versus depth $(d)$ and regression lines for sample potholes at each study site a Bhakuyadi $(n=115), \mathbf{b}$ Guridih $(n=65)$ and c Ghatsila $(n=35)$ 
$S_{\min }$ and $B_{\min }$. From the sculpted forms $(n=65)$ applying the morphometric parameters $S_{\max } S_{\min }, B_{\max }, B_{\min }$ and $D$ and their interrelationship, it reveals that 35 potholes are in cylindrical, 17 in elliptical and 13 in elongated forms. Surface Index (SI), Bottom Index (BI) and Vertical Index (VI) $(5.58 \mathrm{~cm}, 4.03 \mathrm{~cm}$ and $1.73 \mathrm{~cm})$ data reflect a significant variation among these variables (after 2 feet depth).

\subsubsection{Shape-form analysis applying morphometric and statistical parameters (Site 3 Ghatsila $n=35$ )}

In case of sample Site 3 Ghatsilan $=35$ (Table 8), the largest surface and bottom diameter $\left(S_{\max }\right.$ and $\left.B_{\max }\right)$ are $138.00 \mathrm{~cm}$ and $92.00 \mathrm{~cm}$, respectively, whereas the smallest diameter at the surface and bottom $\left(S_{\min }\right.$ and $\left.B_{\text {min }}\right)$ are $36.00 \mathrm{~cm}$ and
$26.00 \mathrm{~cm}$. On the other hand, the maximum vertical depth (D) is $138.00 \mathrm{~cm}$, while mean depth is $27.96 \mathrm{~cm}$. Coefficient of variation (in \%) shows that $S_{\max }$ and $B_{\max }$ are more consistent with respect to $S_{\min }$ and $B_{\min }$. Therefore, it is found that the growth of both top and bottom apertures is connected to the fluvio-hydrological parameters. Applying the morphometric parameters of potholes $\left(S_{\max } S_{\min ^{\prime}} B_{\max } B_{\min }\right.$ and $D$ ) and their interrelationship, it reveals that 16 potholes are in cylindrical, 11 in elliptical and 8 in elongated forms. Surface Index (SI), Bottom Index (BI) and Vertical Index (VI) $(3.83 \mathrm{~cm}, 3.53 \mathrm{~cm}$ and $2.00 \mathrm{~cm})$ data show no significant variation due to less microstructural imprints like fractures and joints with respect to the above-mentioned two sites.

Table 6 Statistics of erosional channel bed potholes of Subarnarekha river site-Bhakuyadi $(n=115)$

\begin{tabular}{|c|c|c|c|c|c|c|c|c|}
\hline Parameters & $S_{\max }$ & $S_{\min }$ & $\mathrm{D}$ & $B_{\max }$ & $B_{\min }$ & $\mathrm{SI}$ & $\mathrm{BI}$ & VI \\
\hline Radius (cm) & 110.00 & 21.00 & & 85.00 & 18.50 & 5.23 & 4.59 & 1.72 \\
\hline Diameter (cm) & 220.00 & 42.00 & 190.00 & 170.00 & 37.00 & & & \\
\hline Mean $(\mathrm{cm})$ & 49.50 (radius) & 25.10 (radius) & 60.96 & 40.81 (radius) & 23.92 (radius) & & & \\
\hline Standard deviation (SD) & 7.07 & 5.00 & 7.81 & 6.40 & 4.89 & & & \\
\hline Coefficient of variation in \% (cv) & 14.28 & 19.92 & 12.80 & 15.68 & 20.37 & & & \\
\hline
\end{tabular}

Largest radius/diameter at the surface $\left(S_{\max }\right)$, smallest radius/diameter at the surface $\left(S_{\text {min }}\right)$, maximum vertical depth (D), largest radius/ diameter at the bottom $\left(B_{\max }\right)$, smallest radius/diameter at the bottom $\left(B_{\min }\right)$, Surface Index $(\mathrm{SI})$, Bottom Index $(\mathrm{BI})$ and Vertical Index $(\mathrm{VI})$

Table 7 Statistics of erosional channel bed potholes of Rarhu river site-Guridih (near Jhona falls) $(n=65)$

\begin{tabular}{|c|c|c|c|c|c|c|c|c|}
\hline Parameters & $S_{\max }$ & $S_{\min }$ & $D$ & $B_{\max }$ & $B_{\min }$ & SI & $\mathrm{BI}$ & VI \\
\hline Radius (cm) & 95.00 & 17.00 & & 63.00 & 15.60 & 5.58 & 4.03 & 1.73 \\
\hline Diameter (cm) & 190.00 & 34.00 & 165 & 126.00 & 31.20 & & & \\
\hline Mean $(\mathrm{cm})$ & 28.50 (radius) & 16.50 (radius) & 38.20 & 21.38 (radius) & 17.65 (radius) & & & \\
\hline Standard deviation (SD) & 5.38 & 4.12 & 6.16 & 4.58 & 4.24 & & & \\
\hline Coefficient of variation in \% (cv) & 18.87 & 24.96 & 16.12 & 21.42 & 24.00 & & & \\
\hline
\end{tabular}

Largest radius/diameter at the surface $\left(S_{\max }\right)$, smallest radius/diameter at the surface $\left(S_{\min }\right)$, maximum vertical depth (D), largest radius/ diameter at the bottom $\left(B_{\max }\right)$, smallest radius/diameter at the bottom $\left(B_{\min }\right)$, Surface Index $(\mathrm{SI})$, Bottom Index (BI) and Vertical Index (VI)

Table 8 Statistics of erosional channel bed potholes of Subarnarekha river site-near Ghatsila $(n=35)$

\begin{tabular}{|c|c|c|c|c|c|c|c|c|}
\hline Parameters & $S_{\max }$ & $S_{\min }$ & $D$ & $B_{\max }$ & $B_{\min }$ & SI & $\mathrm{BI}$ & VI \\
\hline Radius (cm) & 69.00 & 18.00 & & 46.00 & 13.00 & 3.83 & 3.53 & 2.00 \\
\hline Diameter (cm) & 138.00 & 36.00 & 138 & 92.00 & 26.00 & & & \\
\hline Mean $(\mathrm{cm})$ & 24.60 (radius) & 12.56 (radius) & 27.96 & 19.98 (radius) & 16.83 (radius) & & & \\
\hline Standard deviation (SD) & 5.00 & 3.60 & 5.29 & 4.47 & 4.12 & & & \\
\hline Coefficient of variation in \% (cv) & 20.32 & 28.66 & 18.91 & 22.37 & 24.48 & & & \\
\hline
\end{tabular}

Largest radius/diameter at the surface $\left(S_{\max }\right)$, smallest radius/diameter at the surface $\left(S_{\min }\right)$, maximum vertical depth (D), largest radius/ diameter at the bottom $\left(B_{\max }\right)$, smallest radius/diameter at the bottom $\left(B_{\min }\right)$, Surface Index (SI), Bottom Index (BI) and Vertical Index (VI) 


\section{Discussions}

\subsection{Pothole dynamics controlled by lithology and lineament}

Uneven distribution and multi-dimensional growth rate of channel potholes are due to lithological variations and presence of first-, second- and third-generation structural imprints (fractures, joints, etc.) on the channel beds [44]. Chhota Nagpur granitic gneiss and tonalite gneiss with structural signatures prefer to develop channel bed potholes within the flow path of Subarnarekha River and the above-mentioned tributaries. In case of Saram (near Hundru falls) and Malghonghsa sites of Subarnarekha and Guridih (near Jhona falls) of Rarhu, plunge pools like potholes are existed due to direct falling of water or existing of knick points. Saram, Malghonghsa and Guridih sites reflect above $10^{\circ}$ surface slope or channel gradient. Slope and slope aspect maps (Fig. 2) show moderate to high $\left(12.5^{\circ}-20.36^{\circ}\right.$ and $\left.20.37^{\circ}-40.54^{\circ}\right)$ degree of slope with multi-directions due to lithological variations. Most of the channel bed potholes are situated on Chhota Nagpur granitic gneiss and tonalite gneissic belts except Garanala confluence points (metasediments) due to its moderate to high lineament density (10.5-19.40 km/sq.km) and comparatively low strength with respect to other rocks within the watershed. At the initial stage, lithology with structure and fluvial erosional processes help to accelerate the initiation and growth of potholes.

As a result, the micro-potholes are being initiated and gradually developed in the above-mentioned gneissic rocks on the channel path of Subarnarekha and its tributaries. On the other hand, potholes are almost absent in case of other rocks which also lie on the same channel path.

Firstly dominant sculpted forms are confined in the upstretch of Subarnarekha watershed due to the presence of series of knickpoints on the channel beds of Rarhu, Kanchi and Subarnarekha. Secondly, isolated and scattered small-sized potholes are also found on the channel bed of Karkari and Kharkai tributaries of Subarnarekha due to the absence of knickpoints (along the long profile) and low channel/hydraulic gradients. Valley slope, presence of multi-structural elements of bedrock channel and high to moderate stream power/velocity, discharge with sediment loads help to give birth to fundamental fluvial erosional forms on the channel beds of principal and tributaries streams in the upper stretch section of the abovementioned watershed.

\subsection{Fluvio-hydrological factors controlling pothole growth}

The bottom and wall of the potholes are almost polished surface for the Subarnarekha channel bed and its tributaries. The mechanical abrasion/corrasion is predominant during the formation of potholes on granitic and gneissic rocks. Chemical corrosion (differential dissolution) is also simultaneously acting at the initial growth and development of channel potholes [45]. Due to continuous friction between turbulent fluid and potholes side wall, side wall materials along the fracture plane suddenly collapsed and create eddies within the turbulent flow and lateral growth rate of potholes continuously increase with depth in different sites within the channel planform (Fig. 4). During rainstorm periods, different sized pebbles and sediments (mainly coarse-grained quartz, feldspar sands, etc.) act as mechanical grinders to erode the floor and wall of almost every pothole $[45,46]$. Hydration and granular weathering are prominent on the side wall of the pothole due to alternate wet and dry phase, whereas disintegration of the pothole floors is being restricted due to consistent presence of water at the bottom of the hillside potholes [45]. Similarly, biological activities take place in the water of potholes and various acids discharged which reduce the strength of rocks [46].

The enlargement of the size of the potholes from the initial stage to secondary stage is due to shifting of vortex of turbulent flow along the flow direction, and simultaneously circular or round-shaped potholes are converted to elliptical, oval and sometime elongated shaped depression. At sample Site 1 Bhakuyadi $(n=115)$, it has been noticed that large-sized elongated or elliptical potholes engulfed many small sculpted channel bed potholes due to multi-directional growth along the joints and fractures on the granitic gneiss channel bed of Subarnarekha. Thus, it is clearly indicated that the growth of both top and bottom apertures is connected to the dependence of erosive processes through a positive feedback. Surface Index (SI), Bottom Index (BI) and Vertical Index (VI) $(5.23 \mathrm{~cm}, 4.59 \mathrm{~cm}$ and $1.72 \mathrm{~cm}$ ) data show great variations at particular site due to its multi-structural imprints and variation of fluviohydrological regime. Thus, elliptical and elongated form types are not maintaining the general form rules due to sudden change of channel gradient, stream power and presence of multi-structural elements.

In case of Guridih Site 2, the growth rate of sideward and downward is linked to the dependence of fluvial erosional processes and sudden existence of hydraulic drop (due to change of channel gradient) by a positive feedback mechanism. In case of cylindrical potholes, downward growth rate is more or less stopped due to fixed vortex point $(x)$ and the large particles occupied on bottom floor 
of the potholes. In some cases $\left(S_{\max }>D\right.$ or $\left.B_{\max }>D\right)$, it has been observed that sidewall growth rate is enlarged due to inclination of vortex axis. As a result, along the surface fracture/joints plane conversion takes place from cylindrical shape to elliptical or elongated shape. At that situation, energy has been released in the edge of the sidewall.

At Site 3 Ghatsila, Surface Index (SI), Bottom Index (BI) and Vertical Index (VI) $(3.83 \mathrm{~cm}, 3.53 \mathrm{~cm}$ and $2.00 \mathrm{~cm})$ data show no significant variation due to less microstructural imprints like fractures and joints respect to the abovementioned two sites. At lower stretch (from Ghatsila to confluence), Subarnarekha River has low velocity, channel gradient and wide width. As a result, potholes were developed on gneissic channel bed through longer time span by natural fluvial processes with favorable geological environment. Applying Eqs. (2-4) at three sites (Subarnarekha and its tributaries), most of the potholes are found cylindrical shaped following elliptical and elongated shaped. But many potholes at Guridih and Bhakuyadi sites have been observed with no such above-mentioned shaped during their initiation and gradual growth stage because of the complexity of lithological as well as fluvio-hydrological factors although many authors [47] opined that individual stream potholes have sometime common but their own identical shape.

\subsection{Relationship between depth and radius in the growth of potholes}

The marine potholes show higher average $\mathrm{D} / \mathrm{h}$ ratios than the stream potholes because streams/rivers posses greater erosional probability of bed rock in comparison with marine beachrock [46]. Ji et al. [46] observed that marine waves bring small- to moderate-sized drilling tools for the development of coastal beach potholes, while streams/rivers carry different sized drilling tools (during devastating flood) to form the channel bed potholes considering the hydraulic power. During the maturity stage of river potholes, usually depth exceeds the diameters and hence $D / h$ is a scientific indicator of hydraulic power [46].

There is a close relationship between depth and radius of individual channel bed pothole, and sometimes, it is very difficult to find out the relationship between depth and radius due to dynamic fluvial hydraulics and complicated geological structures. Extensive field-based study had been conducted at three sample sites (Site 1 Bhakuyadi $n=115$, Site 2 Guridih $n=65$ and Site 3 Ghatsila $n=35$ ) to calculate side wall and downward growth on Precambrian rock strata. Individual depth, radius/diameter and form are measured during pre-monsoon with the help of measuring tape. The well-defined relationship between depth and radius (sample Sites 1,2 and 3) is strong evidences to support enlargement of potholes along $y$ and $z$ direction. Progressive change of potholes provides large diameter/radius but shallow depth, and it gets gradually increased in shape and form through time. The effect of amalgamation of potholes brings sudden new shape but through long span of time, potholes subsequently maintain symmetrical depth-radius ratio (Fig. 4). In case of multi-joints and fractures, bottom diameter/radius is restricted and initial vortex point has been shifted toward the side wall. As a result, along the structural weakness new micro-sculpted form is being formed in asymmetrical direction. A total of $n=215$ studied potholes from three sample sties on channel beds of Precambrian geological sites, it is estimated that the vertical depth threshold (VDT) is $60 \mathrm{~cm}$ after which the further downward growth is almost stopped leading to commencement of sidewall growth due to the existence of geological structures within the VDT. Ji et al. [46] applied the formula $D=\mathrm{Nh}+M$ (where $D$ is the mean diameter, $h$ is the depth, $N$ is the relative ratio between deepening and widening of pothole and $M$ is critical size of mean dimensional threshold) to understand the pothole depth and diameter relationship for different categories of potholes and it is found that the growth of mean diameter (D) of pothole increases linearly in proportion to the depth (h) of pothole. The above-mentioned proved hypothesis is widely applicable for river/stream pothole during the initiation phase and gradual growth of the pothole. In other cases, erosion rate is faster at the pothole floor than wall for stresses released on grinders within the pothole. Similarly, erosion on the pothole floor is greater than the wall due to the coarser grinder materials which are acting on the floor of pothole. The large-sized sculpted potholes are found at both the sites like Bhakuyadi and Guridih, and coarse sands, pebbles and small cobbles are also found within the floor of the potholes. These materials swirl within the pothole and gradually erode the valley floor and walls during devastating flood or high discharge in the monsoon period. In few cases, larger blocks are also trapped within the potholes. These blocks normally arrest to erode the side wall as well as valley floor from the erosion. At Bhakuyadi, most of the potholes are occupied in the intersection of joints and fractures which can increase the gradual growth of the pothole over time.

In order to acquire the growth rate of the sculpted forms, the morphometric parameters (mean radius, depth and shape) are used. The study (at three sample sites) found that when the mean radius is greater than the depth, then the directional growth will be increased, but if the depth is greater than mean radius, then the sidewall growth rate will be restricted. In case of oval and elongated shaped potholes, mean radius does not give enough information regarding the growth because multi-structural elements accelerate multi-directional growth as well as rapid increase in radius/diameter (Fig. 4). The log-log linear relation between the depth and radius of three sites (Site 1 Bhakuyadir $^{2}=0.711$, Site 2 Guridihr $^{2} 0.914$ and Site 3 
Ghatsilar $^{2} 0.913$ ) reveal that there is strong linear proportional relationship (Fig. 5).

\section{Conclusions}

The comprehensive study of bedrock potholes on the channel bed of Subarnarekha and its tributaries (at different stretches in Precambrian sites) of Chhota Nagpur plateau of Indian peninsula shows systematic and fundamental theory building results such as

(i) The origin, location, growth and potholes dynamics are largely controlled by local condition such as lithology with structure and fluvio-hydrological attributes. The formation of hydraulic drops at different stretches is due to the existence of knickpoints along the course of Subarnarekha River and its tributaries. The moderate to high lineament density $(10.5-19.40 \mathrm{~km} / \mathrm{sq} . \mathrm{km})$ exists on Chhota Nagpur granitic gneiss, tonalite gneiss and Singhbhum metasediments. Similarly, the dominant potholes are confined in the above-mentioned Precambrian geological sites due to the presence of multi-structural elements (joints, fractures, etc.).

(ii) The result of statistical analysis shows that there is a strong positive correlation between depth and radius of potholes. Similarly, the gradual sidewall $(y)$ and downward ( $z$ ) expansion indicate consistent growth.

(iii) A total of $n=215$ studied potholes from three sample sties on channel beds of Precambrian geological sites of Indian peninsula, and it is ultimately found that the vertical depth threshold (VDT) is $60 \mathrm{~cm}$ (approx.).

(iv) Considering the mathematical equation (y), it is clearly revealed that the enlargement of the size of the potholes from initial stage to secondary stage is mainly due to shifting of vortex, and as a result, circular/round-shaped potholes are converted to elliptical/oval/elongated shaped potholes (presence of surface multi-directional structural weakness). At Site 1 Bhakuyadi $(n=115)$, the amalgamation process is still active due to rapid change of channel gradient and presence of joints, fractures, etc.

(v) The study of fluvio-hydrological response within Subarnarekha watershed clearly reflects localized fluvio-hydrological factors (like corrasion, corrosion, cavitation and hydraulic action, etc., change of channel gradient, monsoonal bankfull discharge and formation of hydraulic drop) control the dynamics of bedrock channel potholes. (vi) Applying morphometric indexes like Surface Index $(\mathrm{SI})$, Bottom Index (BI) and Vertical Index (VI) at Bhakuyadi $(n=115)$, Guridih $(n=65)$ and Ghatsila $(n=35)$, it is found that most of the channel bed potholes are cylindrical form although elliptical and elongated form types of potholes are also found due to sudden change of channel gradient, stream power and poly-directional joints and fractures on gneissic and granitic rocks.

Acknowledgements We express our sincere gratitude to the Director of Geological Survey of India for their constant help and assistance.

\section{Compliance with ethical standards}

Conflicts of interest The authors declare that they have no conflict of interest.

\section{References}

1. Zhong J, Ni J, Shen X (2002) Study of potholes in the lower reaches of the Yellow River. Acta Geol Sin 76(2):280-286

2. Tonglin $\mathrm{H}$, Xiong $\mathrm{L}$, Guo K (2001) A discussion on the origin of moulins in South China (2). Trop Geogr 21(2):189-194

3. Zhao G, Zhu H, Li P (2001) Quaternary glacial geology and origin of glacial pothole swarms in Inner Mongolia. Reg Geol China 20(2):200-206

4. Wang W, Liang M, Huang S (2009) Formation and development of stream potholes in a gorge in Guangdong. J Geogr Sci 19(1):118-128. https://doi.org/10.1007/s11442-009-0118-9

5. Hancock GS, Anderson RS, Whipple KX (1998) Beyond power, bedrock incision process and form. In: Tinkler KJ, Wohl EE (eds) Rivers over rock: fluvial processes in bedrock channels. Geophysical monograph series, vol 107. AGU, Washington, D.C., pp 35-60

6. Whipple KX, Hancock GS, Anderson RS (2000) River incision into bedrock: mechanics and relative efficacy of plucking, abrasion, and cavitation. Geol Soc Am Bull 112:490-503. https://doi.org/10.1130/0016-7606(2000)112\%3c490:RIIBM A\%3e2.0.CO;2

7. Whipple KX, Snyder NP, Dollenmayer K (2000) Rates and processes of bedrock incision by the Upper Ukak River since the 1912 Novarupta ash flow in the Valley of Ten Thousand Smokes, Alaska. Geology 28:835-838. https://doi.org/10.1130/00917613(2000)28\%3c835:RAPOBI\%3e2.0.CO;2

8. Stark CP, Stark GJ (2001) A channelization model of landscape evolution. Am J Sci 301:486-512. https://doi.org/10.2475/ ajs.301.4-5.486

9. Springer GS, Wohl EE (2002) Empirical and theoretical studies of sculpted forms in Buckeye Creek Cave, West Virginia. J Geol 110:469-481. https://doi.org/10.1086/340442

10. Stock GM, Anderson RS, Finkel RC (2004) Pace of landscape evolution in the Sierra Nevada, California, revealed by cosmogenic dating of cave sediments. Geology 32:193-196. https://doi. org/10.1130/G20197.1

11. Whipple KX (2004) Bedrock rivers and the geomorphology of active orogens. Ann Rev Earth Planet Sci 32:151-185. https:// doi.org/10.1146/annurev.earth.32.101802.120356 
12. Springer GS, Tools T, Wohl TT (2005) Dynamics of pothole growth as defined by field data and geometrical description. J Geophys Res 110:F04010. https://doi.org/10.1029/2005JF000321.a

13. Blumberg PG, Curl RL (1974) Experimental and theoretical studies of dissolution roughness. J Fluid Mech 65:735-751. https:// doi.org/10.1017/S0022112074001625

14. Curl RL (1974) Deducing flow velocity in cave conduits from scallops. NSS Bull 36(2):1-5

15. Ortega JA, Gomez-Heras M, Perez-Lopez R (2013) Multiscale structural and lithologic controls in the development of stream potholes on granite bedrock rivers. Geomorphology 204:588598. https://doi.org/10.1016/j.geomorph.2013.09.005

16. Elston ED (1917) Potholes: their variety, origin and significance. (I). Sci Mon 5:554-567

17. Goode JR, Wohl E (2010) Coarse sediment transport in a bedrock channel with complex bed topography. Water Resour Res 46:W11532. https://doi.org/10.1029/2009WR008135

18. Springer GS, Tools T, Wohl TT (2006) Theoretical modeling of stream potholes based upon empirical observations from the Orange River, Republic of South Africa. Geomorphology 82(1/2):160-176. https://doi.org/10.1016/j.geomo rph.2005.09.023

19. Alexander HS (1935) Pothole erosion. J Geol 40(4):305-337. https://doi.org/10.1086/623954

20. Reed JC Jr, Sigafoos RS, Fisher GW (1980) The river and the rocks. US Geol Surv Bull 1471:75

21. Dionne JC, Twidale CR (1982) Granite Landforms, AmsterdamNew York-Oxford, Elsevier, 372 p., 301 fig., bibliogr., index, $17 x$ $25 \mathrm{~cm}, 115 \$$ US ou 148, 35\$ can. Géog Phys Quatern 38(2):209210. https://doi.org/10.7202/032556ar

22. Zen E, Prestegaard KL (1994) Possible hydraulic significance of two kinds of potholes: examples from the paleo-Potomac River. Geology 22(1):47-50. https://doi.org/10.1130/00917613(1994)022\%3c0047:PHSOTK\%3e2.3.CO;2

23. Thompson GH Jr (1990) Geomorphology of the lower Susquehanna River gorge: Lancaster, Pennsylvania. In: Pennsylvania geologists 55th annual field conference guidebook, pp 86-106

24. Yalin MS (1992) River mechanics, vol 219. Elsevier, New York. ISBN: 9781483287294

25. Zhaoxuan Z (1958) A brief discussion on the landforms of Hanjiang upper reach. J South China Norm Univ 3:121-165

26. Zhu Z (2000) A preliminary investigation on landform and weathered horizon in a river valley in Jiexi County, Guangdong Province. Trop Geogr 20(4):331-336

27. Cui Z, Li H, Nan L, Li D (1999) The discovery and environmental significance of Chifeng wind route and huge pots of Inner Mongolia and Hebei Province. Chin Sci Bull 44(16):1531-1536. https ://doi.org/10.1007/BF03183580

28. CBPCWP (1986) Assessment and development study of river basin series ADSORBS/15/1985-86. Basin sub basin inventory of water pollution: The Subarnarekha River basin; Central Board for the Prevention and Control of Water Pollution (CBPCWP), New Delhi.

29. Giri S, Singk AK (2014) Assessment of human health risk for heavy metals in fish and shrimp collected from Subarnarekha River, India. Int J Environ Res Pub Health 24:429-449. https://doi. org/10.1007/s11356-015-4813-z

30. Mukhopadhyay SC (1973) River terraces of the Subarnarekha basin. Geogr Rev India 35(2):152-170 (Geographical Society of India, Calcutta)

31. Mark DM (1983) Relation between field-surveyed channel network and map-based geomorphometric measures, Inez
Kentucky. Ann Assoc Am Geogr 73(3):358-372. https://doi. org/10.1111/j.1467-8306.1983.tb01422.x

32. Ozdemir H, Bird D (2009) Evaluation of morphometric parameters of drainage networks derived from topographic maps and DEM in point of floods. Environ Geol 56:1405-1415. https://doi. org/10.1007/s00254-008-1235-y

33. Band LE (1986) Topographic partition of watersheds with digital elevation models. Water Resour Res 22(1):15-24. https://doi. org/10.1029/WR022i001p00015

34. Morris DG, Heerdegen RG (1988) Automatically derived catchment boundaries and channel networks and their hydrological applications. Geomorphology 1:131-141. https://doi. org/10.1016/0169-555X(88)90011-6

35. Tarboton DG, Bras RL, Rodriguez-Iturbe I (1991) On the extraction of channel networks from digital elevation data. Hydrol Process 5:81-100. https://doi.org/10.1002/hyp.3360050107

36. Gurnell AM, Montgomery AR (1999) Hydrological applications of GIS. Wiley, Chichester, p 176. ISBN: 978-0-471-89876-4

37. Maidment DR (2002) ArcHydro GIS for water resources. Esri Press, California. ISBN-13: 978-1589480346

38. Mostafa M, Zakir F (1996) New enhanced techniques for azimuthal analysis of lineaments for detecting tectonic trends in and around the Afro-Arabian Shield. Int J Remote Sens 17:29232943. https://doi.org/10.1080/01431169608949119

39. Zakir F, Qari M, Mostfa M (1999) A new optimising technique for preparing lineament density maps. Int J Remote Sens 20:10731085. https://doi.org/10.1080/014311699212858

40. Hung LQ, Batelaan O, De Smedt F (2005) Lineament extraction and analysis, comparison of LANDSAT ETM and ASTER imagery. Case study: Suoimuoi tropical karst catchment, Vietnam. In: M Ehlers, U Michel (eds) Remote sensing for environmental monitoring, GIS applications, and geology V, proceedings of SPIE, vol 59830. https://doi.org/10.1117/12.627699

41. Miller JR (1991) The influence of bedrock geology on knickpoint development and channel bed degradation along down cutting streams in south-central Indiana. J Geol 99:591-605. https://doi. org/10.1086/629519

42. Wohl E, Kuzma JN, Brown NE (2004) Reach-scale channel geometry of a mountain river. Earth Surf Process Landf 29:969-981. https://doi.org/10.1002/esp.1078

43. Leopold LB (1994) A view of the river. Harvard University Press Cambridge, Massachusetts

44. Kanhaiya S, Singh S, Singh CK, Srivastava VK (2019) Pothole: a unique geomorphological feature from the bedrocks of Ghaghghar River, Son valley, India. Geol Ecol Landsc. https:// doi.org/10.1080/24749508.2018.1558018

45. Ji S (2017) Rainstorm-induced erosion as a mechanism for the formation of hillside potholes. Geotectonica et Metallogenia 41(6):1039e52. https://doi.org/10.16539/j.ddgzyckx.2017.06.004

46. Ji S, Li L, Zeng W (2018) The relationship between diameter and depth of potholes eroded by running water. J Rock Mech Geotech Eng 10(5):818-831. https://doi.org/10.1016/j.jrmge .2018.05.002

47. Basu SR, Bera B (2010) Text book of hydrology. Levant Books, Sarat Book Distributors, Kolkata. ISBN 978-93-80663-00-5

Publisher's Note Springer Nature remains neutral with regard to jurisdictional claims in published maps and institutional affiliations. 